Research Article

\title{
Drinking water and sanitation: household survey for knowledge and practice in rural area, Magudanchavadi, Salem district, India
}

\author{
Ravi Pachori* \\ Department of Community Medicine, Hind Institute of Medical Science, Mau, Ataria, Sitapur, Uttar Pradesh, India \\ Received: 16 May 2016 \\ Accepted: 07 June 2016 \\ *Correspondence: \\ Dr. Ravi Pachori, \\ E-mail: dr_ravipachori@doctor.com \\ Copyright: ( ) the author(s), publisher and licensee Medip Academy. This is an open-access article distributed under \\ the terms of the Creative Commons Attribution Non-Commercial License, which permits unrestricted non-commercial \\ use, distribution, and reproduction in any medium, provided the original work is properly cited.
}

\begin{abstract}
Background: Water is basic human right, most precious resource for economy and health. Sanitation is determinants of quality of life and individual's hygiene can affect the whole community. Drinking water and sanitation is a fundamental health service.

Methods: It is a community based cross sectional study conducted in Rural Health Training centre, Magudanchavadi, the field practice area of Annapoorana Medical College and hospital, Salem, Tamilnadu. Sample size was calculated through the universal formula $\mathrm{n}=\mathrm{z} 2 \mathrm{pq} / \mathrm{d} 2$ and sample size was finalized to 300 houses. Data was compiled in MS Excel and analyzed in institutional SPSS version 16.

Results: Out of 300 households adult females were 154 (51.3\%), literacy level was till matriculation 160 (53.3\%) and families belonged to middle class 154 (51.3\%). Households had knowledge of covered drinking water 289 (96.3\%), clean drinking water $255(85 \%)$, covered garbage dustbin $185(61.7 \%)$, sanitary toilet $249(83 \%)$ and hand wash after toilet $282(94 \%)$. Households were practiced covered drinking water $284(94.7 \%)$, collected water for drinking purpose from pipeline $256(85.3 \%)$, boiling method used for purification of drinking water $136(45.3 \%)$, uncovered garbage dustbin 162 (54\%), garbage found openly in premises $173(57.3 \%)$, toilet facility $188(62.7 \%)$, open air defecation $97(32.3 \%)$ and hand wash after toilet with soap $198(66 \%)$. Their knowledge was significantly associated with practice of it.

Conclusions: Knowledge was good enough but unhealthy practices make health education very important for better use of existing facilities and also to prevent the incidences of water and sanitation related diseases.
\end{abstract}

Key words: Knowledge, Practice, Drinking water, Sanitation

\section{INTRODUCTION}

Water is the essence of life and basic human right essential to all and for sustainable development. It is known that drinking water is our most precious resource for our economy, our daily lives and to the health of our environment. ${ }^{1}$ Sanitation is one of the determinants of quality of life and human development index. It has been both public and private elements, and the individual's hygiene can affect the whole community. Drinking water and sanitation is a fundamental health service without which there cannot be any improvement. Drinking water and sanitation inadequacies hinder economic and social development, constitute a major hurdle to poverty alleviation and inevitably lead to environmental degradation. ${ }^{2}$

The year 2005 marked the beginning of the "International Decade for Action: Water for Life" and renewed effort to achieve the Millennium Development Goal (MDG) 7, target 10 aims to reduce by half the proportion of the world's population without sustainable access to drinking 
water and sanitation by $2015 .^{3}$ Globally, almost three quarters of them live in rural areas and only half of the rural population uses an improved sanitation facility. Assessing progress towards the MDG target alone creates an incomplete picture and countries that started out with low baseline coverage have had to work much harder to halve the proportion of the population without water and sanitation. This is the added challenge of rapid population growth and moreover it is the poorest countries that are often characterized by a combination of low baseline coverage and high population growth. The world is unlikely to meet the MDG sanitation target by 2015 . $^{4}$

Drinking water and sanitation is the door way to health which is the pre-requisite for progress, social equity and human dignity to improve the quality of life of people. It is one of the most important felt needs in public health in developing countries in this $21^{\text {st }}$ century. ${ }^{5}$ However, it is still an ignored issue in India and lack of drinking water and adequate sanitation is a key contributing factor to the ongoing high rates of health related disease noted in developing countries. ${ }^{6}$ India is still lagging far behind many countries in the field of drinking water and sanitation in which most of the problems in the country are due to defective environment, which in turn rob people of their health, destroy their livelihoods and undermine their overall development potential and improvement in drinking water and sanitation has been consistently identified as being an important intervention to improve health. ${ }^{7}$

Objective of the study was to assess the sociodemographic profile, to assess the knowledge on drinking water and sanitation among people residing in the field practice area of Annapoorna Medical College, Salem and to assess the practice on drinking water ,sanitation and hygiene among people residing in the field practice area of Annapoorna Medical College, Salem and to find the association between knowledge and practice related to drinking water and sanitation

\section{METHODS}

It is a community based cross sectional study conducted during March 2014 in Rural Health Training centre, Magudanchavadi, the field practice area of Annapoorana Medical College \& hospital, Salem, Tamilnadu. Field practice area covers 8,871 population (2011 census) and most of them were involved in small scale industries mainly cotton mills and home based or network based weaving. The sampling units were the households and sample size was calculated based on the universal formula $\mathrm{n}=\mathrm{z} 2 \mathrm{pq} / \mathrm{d} 2$ where in, $\mathrm{z}=1.96$, (at $95 \%$ confidence levels), $\mathrm{p}=78.5$ (access to drinking water nearby premises in rural Salem, Tamilnadu), q (1-p) = 21.5, Absolute precision ' $\mathrm{d}$ ' taken at $5 \%=0.05 .^{8}$ Using the above formula, the sample size calculated was 270 , and accounting for $10 \%$ nonresponsive, the sample size calculated was 297. Therefore sample size of the study was finalized to 300 houses.
Structured questionnaires were prepared, which include the basic sociodemographic profile, knowledge and practice questions regarding drinking water and sanitation of households in the rural communities of the study area. The questionnaire was pre-tested in few selected household. The pre-test was conducted near the study area which had similar characteristics to the areas where the actual study was carried out. Vague terms, phrases and questions identified during the pre-test were modified and changed and missing responses like 'no response' and 'others' were added, and skipping patterns were also corrected. The questionnaires were then administered to the selected study households at their respective residential places.

A pre-tested restructured questionnaire was used as a tool for the study and study was carried out by house to house visit. Convenient purposive sampling technique was applied because the sampling frame of the population of that area was not available. Interview was conducted face to face and study subjects were enrolled till the required sample size was met. Information was collected by interviewing the available adult family member at the time of visit, and also, by physical examination of facilities. Consent was taken from the household member and those families which were not available at their houses and who didn't give consent were excluded.

Data collected were compiled in MS Excel software and analyzed in institutional SPSS version 16. Variables of knowledge and practice of drinking water and sanitation were analyzed either by chi square or Fischer exact test, data was presented in percentages (\%) and proportions form and statistical significance was considered at 0.05 level.

\section{RESULTS}

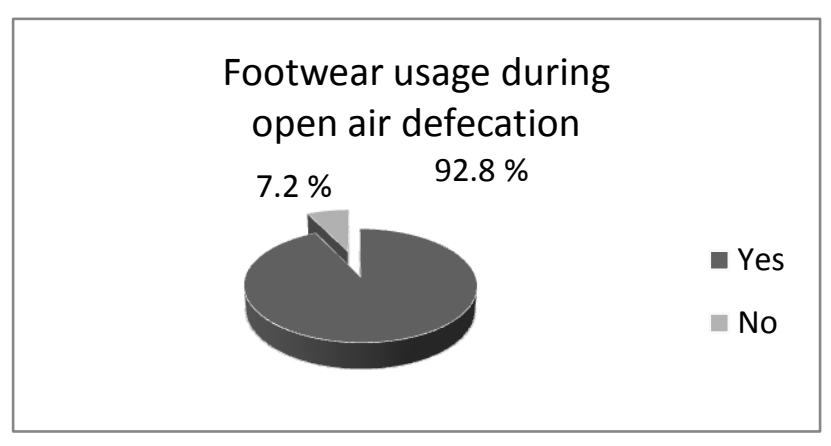

Figure 1: Pie chart showing percentage of people using footwear during open air defecation.

$81(27 \%)$ of them were illiterate, out of whom 154 $(51.3 \%)$ of families belonged to middle class and 90 $(30 \%)$ of families belonged to the upper socioeconomic class according to Convenient form of modified B.G. Prasad revised income categories for all India (IW) 2014 as shown in Table (1). 
Most of households had knowledge about the importance of covered drinking water $289(96.3 \%)$ followed by clean drinking water $255(85 \%)$, cleaning of river/pond water 219 (73\%), covered garbage dustbin 185 (61.7\%), sanitary toilet $249(83 \%)$ and hand wash after toilet 282 $(94 \%)$ as shown in table (2).

Table 1: Distribution of study subjects by sociodemograhic characteristic $(n=300)$.

\begin{tabular}{|c|c|c|c|}
\hline \multicolumn{2}{|c|}{$\begin{array}{l}\text { Sociodemograhic } \\
\text { characteristics }\end{array}$} & $\begin{array}{l}\text { Frequency } \\
\text { (n) }\end{array}$ & $\begin{array}{l}\text { Percent } \\
(\%)\end{array}$ \\
\hline \multirow[t]{3}{*}{ Age } & $20-40$ & 159 & 53.0 \\
\hline & $41-60$ & 110 & 36.7 \\
\hline & $>60$ & 31 & 10.3 \\
\hline \multirow[t]{2}{*}{ Sex } & Male & 146 & 48.7 \\
\hline & Female & 154 & 51.3 \\
\hline \multirow[t]{3}{*}{ Education } & illiterate & 81 & 27.0 \\
\hline & High school & 160 & 53.3 \\
\hline & $>$ High school & 59 & 19.7 \\
\hline \multirow[t]{3}{*}{ Occupation } & unemployed & 56 & 18.7 \\
\hline & skilled & 145 & 48.3 \\
\hline & unskilled & 99 & 33.0 \\
\hline \multirow{3}{*}{$\begin{array}{l}\text { Convenient } \\
\text { form of } \\
\text { modified B.G. } \\
\text { Prasad } \\
\text { revised income } \\
\text { categories } \\
\text { for all India } \\
\text { (IW) } 2014\end{array}$} & Lower class & 56 & 18.7 \\
\hline & Middle class & 154 & 51.3 \\
\hline & Upper class & 90 & 30.0 \\
\hline Total & & 300 & 100.0 \\
\hline
\end{tabular}

Table 2: Distribution of study subjects by Knowledge on drinking water and sanitation.

\begin{tabular}{|c|c|c|c|}
\hline Knowledge & $\mathbf{N}=\mathbf{3 0 0}$ & $\begin{array}{l}\text { No. of } \\
\text { houses (n) }\end{array}$ & $\begin{array}{l}\text { Percentage } \\
(\%)\end{array}$ \\
\hline \multirow{2}{*}{$\begin{array}{l}\text { Drinking water } \\
\text { should be } \\
\text { covered }\end{array}$} & Yes & 289 & 96.3 \\
\hline & No & 11 & 3.7 \\
\hline \multirow{2}{*}{$\begin{array}{l}\text { Clean drinking } \\
\text { water should be } \\
\text { used }\end{array}$} & Yes & 255 & 85.0 \\
\hline & No & 45 & 15.0 \\
\hline \multirow{2}{*}{$\begin{array}{l}\text { Rivers/Ponds } \\
\text { water should be } \\
\text { clean }\end{array}$} & Yes & 219 & 73 \\
\hline & No & 81 & 27 \\
\hline \multirow{2}{*}{$\begin{array}{l}\text { Garbage dustbin } \\
\text { should be } \\
\text { covered }\end{array}$} & Yes & 185 & 61.7 \\
\hline & No & 115 & 38.3 \\
\hline \multirow{2}{*}{$\begin{array}{l}\text { Sanitary Toilet } \\
\text { should } \\
\text { be used }\end{array}$} & Yes & 249 & 83.0 \\
\hline & No & 51 & 17.0 \\
\hline \multirow{2}{*}{$\begin{array}{l}\text { Hand wash after } \\
\text { toilet }\end{array}$} & Yes & 282 & 94.0 \\
\hline & No & 18 & 6.0 \\
\hline Total & & 300 & 100 \\
\hline
\end{tabular}

A total of 300 households were visited for the study purpose. Most of the respondents were adult females 154 $(51.3 \%)$ and belonged to 20-40 years age group 159 (53\%). The most common occupation of head of household was skilled $145(48.3 \%)$ followed by unskilled $99(33 \%)$. The literacy level of head of majority of households was till matriculation $160(53.3 \%)$ and around

Table 3: Distribution of study subjects by Hygienic practice on drinking water and sanitation.

\begin{tabular}{|c|c|c|c|}
\hline $\begin{array}{l}\text { Hygienic } \\
\text { practice }\end{array}$ & $\mathbf{N}=\mathbf{3 0 0}$ & $\begin{array}{l}\text { No. of } \\
\text { houses } \\
\text { (n) }\end{array}$ & $\begin{array}{l}\text { Percentage } \\
(\%)\end{array}$ \\
\hline \multirow{2}{*}{$\begin{array}{l}\text { Drinking water } \\
\text { was } \\
\text { found cover }\end{array}$} & Yes & 284 & 94.7 \\
\hline & No & 16 & 5.3 \\
\hline \multirow{2}{*}{$\begin{array}{l}\text { Source of } \\
\text { drinking } \\
\text { water }\end{array}$} & $\begin{array}{l}\text { Pipe line } \\
\text { water }\end{array}$ & 256 & 85.3 \\
\hline & Others* & 44 & 14.7 \\
\hline \multicolumn{4}{|c|}{$\begin{array}{l}\text { Pipe line water }=\text { tube well, tape water, hand pump, } \\
\text { Others* = River/pond/lake }\end{array}$} \\
\hline \multirow{2}{*}{$\begin{array}{l}\text { Distance of } \\
\text { source of } \\
\text { drinking water }\end{array}$} & $\begin{array}{l}\text { Within } \\
\text { premises }\end{array}$ & 135 & 45.0 \\
\hline & $\begin{array}{l}\text { Outside of } \\
\text { premises }\end{array}$ & 165 & 55.0 \\
\hline \multirow{3}{*}{$\begin{array}{l}\text { Water } \\
\text { purification } \\
\text { method }\end{array}$} & Boiling & 136 & 45.3 \\
\hline & Others** & 118 & 39.3 \\
\hline & None & 46 & 15.3 \\
\hline \multicolumn{4}{|c|}{ Others $* *=$ Chlorine tab., Cloth filtration, RO System } \\
\hline \multirow{2}{*}{$\begin{array}{l}\text { Garbage } \\
\text { dustbin was } \\
\text { covered in } \\
\text { premises }\end{array}$} & Yes & 138 & 46.0 \\
\hline & No & 162 & 54.0 \\
\hline \multirow{2}{*}{$\begin{array}{l}\text { Garbage was } \\
\text { found openly in } \\
\text { premises }\end{array}$} & Yes & 173 & 57.7 \\
\hline & No & 127 & 42.3 \\
\hline \multirow[t]{3}{*}{$\begin{array}{l}\text { Toilet facility } \\
\text { was available }\end{array}$} & $\begin{array}{l}\text { Toilet within } \\
\text { premises }\end{array}$ & 188 & 62.7 \\
\hline & $\begin{array}{l}\text { Open air } \\
\text { defecation }\end{array}$ & 97 & 32.3 \\
\hline & $\begin{array}{l}\text { Community } \\
\text { toilet }\end{array}$ & 15 & 5.0 \\
\hline \multirow{2}{*}{$\begin{array}{l}\text { Foot wear used } \\
\text { for toilet }\end{array}$} & Yes & 233 & 77.7 \\
\hline & No & 67 & 22.3 \\
\hline \multirow{2}{*}{$\begin{array}{l}\text { Hand washing } \\
\text { after toilet }\end{array}$} & Soap water & 198 & 66.0 \\
\hline & Others $* * *$ & 102 & 34.0 \\
\hline \multicolumn{4}{|c|}{ Others $* * *=$ Ash, Mud, Plain Water } \\
\hline \multicolumn{2}{|c|}{ Total } & 300 & 100 \\
\hline
\end{tabular}

We found that the access to water facility was $100 \%$ as all the houses derived water from sources. Table (3) was shown covered drinking water was found $284(94.7 \%)$ and majority households $256(85.3 \%)$ collected water for drinking purpose from pipeline followed by remaining others $44(14.7 \%)$. They were travelling for fetching drinking water $165(55 \%)$ outside of premises followed by $135(45 \%)$ within premises. It was seen that majority 
$136(45.3 \%)$ households used boiling method for purification of drinking water followed by 118 (39.3\%) of them treat drinking water by other methods and 46 (15.3\%) households did not use any treatment for purification of water. Average 162 (54\%) households had uncovered garbage dustbin, garbage found openly in premises $173(57.3 \%)$ and households were had a toilet facility within premises $188(62.7 \%)$ of which toilets were sanitary $161(53.7 \%)$, households without toilet facility who used open air defecation 97 (32.3\%), households did not use footwear for toilet 67 (22.3\%), households washed their hands after toilet with soap 198 $(66 \%)$ and remaining by others like as Ash, Mud, Plain Water $102(34 \%)$.

Table 4: Association of knowledge and practice of respondents on drinking water and sanitation.

\begin{tabular}{|c|c|c|c|c|c|c|}
\hline \multirow{3}{*}{ Practice } & \multicolumn{3}{|c|}{ Knowledge } & \multicolumn{3}{|c|}{$\mathrm{CI}=95 \%$} \\
\hline & & Yes $(\%)$ & No $(\%)$ & Total $(\%)$ & $\chi^{2}$ & $P$ value \\
\hline & & \multicolumn{5}{|c|}{ Clean drinking water should be used } \\
\hline \multirow{2}{*}{$\begin{array}{l}\text { Drinking water was found } \\
\text { cover }\end{array}$} & Yes & $249(83.0)$ & $35(11.7)$ & $284(94.7)$ & \multirow[t]{2}{*}{29.909} & \multirow[t]{2}{*}{0.00} \\
\hline & No & $6(2.0)$ & $10(3.3)$ & $16(5.3)$ & & \\
\hline \multirow[t]{2}{*}{ Distance of source of water } & $\begin{array}{l}\text { within } \\
\text { premises }\end{array}$ & $123(41.0)$ & $12(4.0)$ & $135(45.0)$ & \multirow[t]{2}{*}{7.190} & \multirow[t]{2}{*}{0.007} \\
\hline & $\begin{array}{l}\text { Outside of } \\
\text { premises }\end{array}$ & $132(44.0)$ & $33(11.0)$ & $165(55.0)$ & & \\
\hline \multirow{3}{*}{$\begin{array}{l}\text { Water } \\
\text { purification } \\
\text { method }\end{array}$} & Boiling & $130(43.3)$ & $6(2.0)$ & $136(45.3)$ & \multirow[t]{3}{*}{1.479} & \multirow[t]{3}{*}{0.00} \\
\hline & Others & $113(37.7)$ & $5(1.7)$ & $118(39.3)$ & & \\
\hline & None & $12(4.0)$ & $34(11.3)$ & $46(15.3)$ & & \\
\hline \multicolumn{7}{|c|}{ Others $* *=$ Chlorine tab., Cloth filtration, RO System } \\
\hline \multicolumn{7}{|c|}{ Drinking water should be covered } \\
\hline \multirow{2}{*}{$\begin{array}{l}\text { Drinking water was } \\
\text { found cover }\end{array}$} & Yes & $279(93.0)$ & $5(1.7)$ & $284(94.7)$ & \multirow[t]{2}{*}{54.773} & \multirow[t]{2}{*}{0.00} \\
\hline & No & $10(3.3)$ & $6(2.0)$ & $16(5.3)$ & & \\
\hline \multicolumn{7}{|c|}{ Rivers/Ponds water should be clean } \\
\hline \multirow[t]{3}{*}{ Water purification method } & Boiling & $115(38.3)$ & $21(7.0)$ & $136(45.3)$ & \multirow[t]{3}{*}{67.477} & \multirow[t]{3}{*}{0.00} \\
\hline & Others & $93(31.0)$ & $25(8.3)$ & $118(39.3)$ & & \\
\hline & None & $11(3.7)$ & $35(11.7)$ & $46(15.3)$ & & \\
\hline \multicolumn{7}{|c|}{ Garbage dustbin should be covered } \\
\hline \multirow{2}{*}{$\begin{array}{l}\text { Garbage dustbin was } \\
\text { covered in premises }\end{array}$} & Yes & $123(41.0)$ & $15(5.0)$ & $138(46.0)$ & \multirow[t]{2}{*}{81.541} & \multirow[t]{2}{*}{0.00} \\
\hline & No & $62(20.7)$ & $100(33.3)$ & $162(54.0)$ & & \\
\hline \multirow{2}{*}{$\begin{array}{l}\text { Garbage was found openly } \\
\text { in premises }\end{array}$} & Yes & $94(31.3)$ & $79(26.3)$ & $173(57.7)$ & \multirow[t]{2}{*}{9.292} & \multirow[t]{2}{*}{0.002} \\
\hline & No & $91(30.3)$ & $36(12.0)$ & $127(42.3)$ & & \\
\hline \multicolumn{7}{|c|}{ Sanitary Toilet should be used } \\
\hline \multirow[t]{2}{*}{ Toilet within premises } & Yes & $183(61.0)$ & $5(1.7)$ & $188(62.7)$ & \multirow[t]{2}{*}{73.394} & 0.00 \\
\hline & No & $66(22.0)$ & $46(15.3)$ & $112(37.3)$ & & \\
\hline Hand wash after defecation & Soap & $174(58.0)$ & $24(8.0)$ & $198(66.0)$ & 9.824 & 0.002 \\
\hline & Others & $75(25.0)$ & $27(9.0)$ & $102(34.0)$ & & \\
\hline
\end{tabular}

Table (4) showed significant association between different variable of knowledge and practice related to drinking water and sanitation. Knowledge of clean drinking water was significantly related with practice of covered water $249(83 \%)$, distance of source $123(41 \%)$, cleaning and disinfectant for water 243 (96\%). Similarly, knowledge regarding covered drinking water 279 (93\%) and Rivers/Ponds water 208 (96.3) was significantly associated with practice of cleaning and disinfectant for drinking water. Knowledge of covered garbage dustbin was significantly associated with practice of covered garbage dustbin $123(41 \%)$ and garbage found openly in premises $94(31.3 \%)$. Likewise knowledge of sanitary toilet was significantly associated with practice of toilet within premises $183(61 \%)$ and hand wash after defecation 174 (58\%). Table (5) was showing hygiene practice significantly related to toilet facility. Toilet within premises $134(44.7 \%)$ and sanitary toilet within premises $124(66 \%)$ had shown significant association with soap hand washing practice. Figure (1) was shown nearly $90(92.8 \%)$ used footwear during open air defecation. 
Table 5: Association of respondents on hygienic practice.

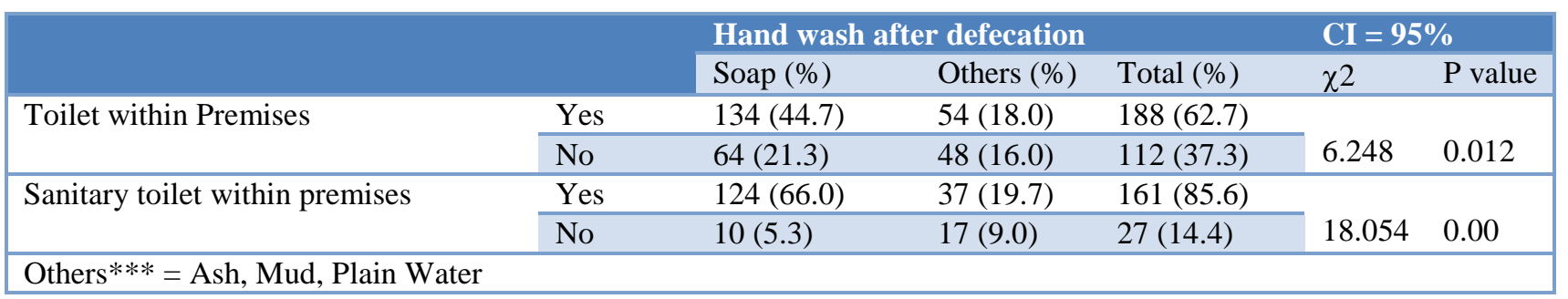

\section{DISCUSSION}

Provision of drinking water has been of primary concern in rural India. ${ }^{9,10}$ In Tamil Nadu, there are guidelines for provision of potable drinking water in villages and to ensure segregation of sewage and drinking water. This includes setting up village level water and sanitation committee to formulate a master plan for sewage and drainage. ${ }^{11}$ These guidelines state that water pipes should not go through sewage or should not be submerged in sewage at any point. However, sewage channels were found to run parallel to water pipes and cross them at various junctions. Since these are open sewage channels, there is the possibility of sewage mixing with the piped water, especially as the water supply is intermittent, causing negative pressure in pipes and after rain, entry of sewage through these taps was a distinct possibility. In order to ensure proper segregation of sewage and faeces from drinking water, alternate designs are needed. Elevating the water pipe at places where water lines cross sewage and covering the sewage channels at junctions are possible methods to minimize contact of sewage with drinking water. ${ }^{12}$

In our study, most of females were homemakers mostly engaged in household activity whereas head of the family was busy in their job. More than half of respondents studied up to matriculation and reported sufficient knowledge about drinking water and sanitation but did not practice it and their economic status was poor as compared to Swaroop N et al. ${ }^{13}$ Study reported that most of respondents had knowledge about importance of covered drinking water in prevention of diseases that was nearly similar to $96.8 \%$ in study by Bharti et al. ${ }^{14}$ Households had higher knowledge about importance of clean drinking water and hand wash after toilet as compared to $(76.92 \%)$ in study of Sah et al. ${ }^{15}$ They had higher knowledge on clean drinking water were significantly associated with implement of covered drinking water practice for better health and protect from water born disease.

The last two decades have seen major shifts in the proportion of the global population using various types of drinking water sources. The biggest change has been the increase in piped water supplies on premises, the use of piped water on premises grew even faster from previous and over the same period, reliance on surface water was halved, in rural areas. ${ }^{4}$ Majority of household significantly practiced covered drinking water in premises as they had knowledge about covered drinking water and $58(58 \%)$ households collected water for drinking purpose from a pipeline which was lower in Swaroop N et al study. ${ }^{13}$ Households who collected water within premises was found similar to 43 (43\%) pipe water in premises and more outside water source respectively comparatively as Swaroop $\mathrm{N}$ et al study and opposite seen in other rural area of Salem district where water source within premises $9 \%$ and outside from premises $91 \%$ respectively. ${ }^{8}$ knowledge on clean drinking water significantly associated to fetching water from outside water source due to there was more chance of water contamination and need to be treated.

It was seen in our study that boiling method more commonly used than straining through cloth for purification of drinking water but Swaroop $\mathrm{N}$ et al showed opposite of it. ${ }^{13}$ The commonest form of disinfection in rural India is single-point chlorination using bleaching powder whereas this may not be effective because of the possibility of multiple sites of contamination and the amount of chlorine added was inadequate by the WHO standards. ${ }^{12,16,17}$ Water is pumped every day but the current TWAD Board guidelines specify that chlorination should be done once a month, thus requiring modification. ${ }^{11}$ Alternative pointof-use disinfection methods such as solar water treatment, point-of-use chlorination and storage of water in narrowmouthed vessels need to be explored. ${ }^{18,19,20,21}$

Considering the contamination of all water samples at the household level, end-user disinfection is likely to be more effective in such settings. ${ }^{22}$ However, such methods may not be sustainable over longer periods or may not be costeffective in rural India. ${ }^{23}$ The practice of tethering animals close to human dwellings and the consequent proximity to animal faecal matter further enhances the risk of contamination of drinking water. ${ }^{24,25}$ The key to providing microbiologically clean drinking water lies in understanding the various mechanisms by which water gets contaminated, and formulating interventions at critical points to decrease and prevent contamination of drinking water. ${ }^{26}$ Approximately 45 (15.3\%) households did not use any treatment for purification of water due to knowledge about clean drinking water and water source 
like river, pond significantly impact on water treatment practice whereas in India average 72.7 per cent of the rural population does not use any method of water disinfection. $^{27}$ Bhattacharya et al. also found $72 \%$ of household don't follow any treatment and drink it as it. ${ }^{28}$ Study reported treating water at home at any point during the year, for the most part seasonally or occasionally rather than year-round. Common triggers for treating water are a change in its appearance or illness in the family mainly increased turbidity during the rainy season may prompt households to treat water, and women often boil water for a sick child or elderly family member and water treatment as a curative, rather than preventive, health measure, to be used in case of sickness. ${ }^{29}$

More than half of households ware significantly had uncovered garbage dustbin and garbage was openly in premises due to lack of knowledge about covered garbage dustbin and health related disease. Knowledge on covered garbage dustbin and sanitary toilet provide protection from breeding places for flies, which transmit cholera, diarrhoea and the dreadful disease of plague, spreads from garbage heaps and it significantly affect households practice. $^{30}$ In India, approximately $74 \%$ have no sanitary toilets facility whereas our study had high proportion of toilet facility as comparatively to toilet facility $72(72 \%)$ in which sanitary toilet facility $62(62 \%)$ in Swaroop N et al study and knowledge about sanitary toilet significantly impact on toilet facility within premises. ${ }^{13,27}$ Households without toilet facility commonly used open air defecation and common public latrine nearly similar to use of public latrine $4.6 \%$ in whole rural area of Salem district. ${ }^{31}$ Open air defecation, a common practice among villagers, may lead to contamination of the water supply system and result in outbreaks of diarrheal disease. ${ }^{32,33}$

Open air defecation more common in our study than other rural area of Salem district. ${ }^{31}$ Open air defecation close to human dwellings contributed to the conversion of large areas of land in and around the village into 'defecation or faecal fields. ${ }^{12}$ These 'faecal fields' potentially put the village at risk of flooding with faecal material from surrounding areas during rains. In an adjoining premises, a suspected outbreak of disease was reported after heavy rain because of poorly maintained water supply pipes that ran through a faecal field. ${ }^{12}$ Existing Tamil Nadu Water Supply and Drainage (TWAD) Board guidelines specify that the public should not defecate around the tanks and the taps, but is nonspecific when it comes to defecation in other places, not accounting for the fact that common defecation areas are usually in the public land where the water supply pipes are laid. ${ }^{11}$ Approximately 67 (22.3\%) of households were not used footwear for toilet and 7 (7.2\%) households didn't used footwear during open air defecation due to almost they were illiterate .

Washing hands after defecation is one of the most effective ways to prevent gastrointestinal parasitic infections. $^{34,35}$ A study of Sah R B et al reported (66\%) wash their hands with soap water after defecation and remaining others like as Ash, Mud, Plain Water 102 (34\%) was same as comparatively to our study in which significant knowledge about sanitary toilet facility affect hand washing practice. ${ }^{36}$ In contrast, studies conducted in Colombia and India reported that $82.5 \%$ and $86.4 \%$ respectively wash their hands after using the toilet. ${ }^{37,38}$ The low frequencies of hand washing with soap significantly attributed to the lack of soap at home and toilet facility in premises. Soap, water, and latrines are essential for proper hygiene practice. $^{39}$ Even if knowledge exists, sanitary toilet facility within premises significantly affect hand wash after defecation and lack of appropriate resources may negatively affect proper hand washing practices. $^{36} \mathrm{~A}$ study by Cairncross et al uncovered the effect of a supportive household norm on hand-washing behaviour was seen on education activities, exhibitions, health camps, local theatre, films and health clubs contributed to the success of a hand-washing promotion programme. ${ }^{29}$

\section{CONCLUSION}

Knowledge regarding drinking water and sanitation among villagers rural area of Salem was good enough but unhealthy surroundings and practices among villagers like as lack of proper toilet facility, poor practice of foot wearing and open air defecation create ideal condition for spread of soil and water transmitted diseases. Health education is very important for better use of existing facilities and also to prevent the incidences of water and sanitation related diseases. Appropriate emphasis is needed to be given to behaviour change communication to create awareness among villagers on the importance of water and sanitation practices by using various media for educate to them.

\section{Funding: No funding sources \\ Conflict of interest: None declared \\ Ethical approval: Not required}

\section{REFERENCES}

1. World Health Organization (WHO) (2004). Water, sanitation and hygiene links to health, facts and figures. Geneva. Available at: http://www.who.int/ water_sanitation_health/ en/ factsfigures04.pdf. Assessed 4 February 2014.

2. Choudury N, Hossain MA. Exploring the current Status of Sanitary latrine use in shibpur Upazila, Narsingdi district. BRAC report. 2006.

3. Moe CL, Rheingans RD. Global challenges in water, sanitation and health. J Water Health. 2006;4 (Suppl 1):41-57.

4. Progress on drinking water and sanitation 2012 update: JMPreport2012. Available at: http://www.unicef.org/ media/ files/ JMPreport2012.pdf. Assessed on $8^{\text {th }}$ February 2014.

5. WHO/UNICEF Joint monitoring programme for water supply and sanitation. Meeting the MDG 
drinking water and sanitation target: a mid-term assessment of progress. World Health Organization, Geneva and United Nations Childrens Fund, New York; 2004. Available at: http://www.who.int/ water_sanitation_health/monitoring/jmpfinal.pdf.

Assessed on $12^{\text {th }}$ February 2014.

6. Howard G, Jahnel J, Frimmel FH, McChesney D, Reed B, Schijven J, et al. Human excreta and sanitation Potential hazards and information Needs. World Health Organization. London UK. IWA Publication:2006.

7. Pandve HT. Environmental sanitation: an ignored issue in India. Indian Journal of Occupational Environmental Medication. 2008;12(1):40. Available at: http://www.ijoem.com/ article.asp. Assessed on $15^{\text {th }}$ Febrary 2014.

8. Tamilnadu: Main source of drinking water, 2011. Available at: http://www.census.tn.nic.in/ HLO_Datasheet_Final/HLO_Datasheet_Drinking_ Water_Page1.pdf. Assessed on $18^{\text {th }}$ February 2014.

9. Bilas R, Singh RP. Rural water supply and the problem of health in village India, case of the Varanasi district. Geogr Med. 1981;11:65-85.

10. Kang G, Ramakrishna BS, Daniel J, Mathan M, Mathan VI. Epidemiological and laboratory investigations of outbreaks of diarrhoea in rural South India: implications for control of disease. Epidemiol Infect. 2001;127:107-12.

11. Tamil Nadu Water Supply and Drainage (TWAD) Board. Guidelines for provision of water supply and hygiene for the village panchayat: book in tamil. Northern Zone, Vellore, Tamil Nadu. Tamil Nadu Water Supply and Drainage Board. Communication and Human Resource Development Division. 2007.

12. Gopal S, Sarkar R, Banda K, Govindarajan J, Harijan BB, Jeyakumar MB. Study of water supply and sanitation practices in India using geographic information systems: some design and other considerations in a village setting. Indian $\mathrm{J}$ Med Res. 2009;129:233-41.

13. Swaroop N, Janish A, Fernandez S, Ramakrishna GB, Agrawal T, Ravi S. Access to improved drinking water and sanitation facilities in a rural area of Bangalore urban district; Nat J Res Com Med. 2012;1(2).

14. Bharti, Malik M, Kumar V, Verma R, Chawla S, Sachdeva S. Knowledge attitude and practices regarding water handling and water quality assessment in a rural block of Haryana. Int J Basic Appl Med Sc. 2013;3(2):243-7.

15. Sah RB, Baral DD, Ghimire A, Pokharel PK. Knowledge \& practice of water \& sanitation application: Health Renaissance. 2013;11(3):241245.

16. Propato M, Uber JG. Vulnerability of water distribution systems to pathogen intrusion: how effective is a disinfectant residual? Environ Sci Technol. 2004;38:3713-22.

17. WHO. Guidelines for cholera control. Geneva: World Health Organization; 1993.
18. Kang G, Roy S, Balraj V. Appropriate technology for rural India - solar decontamination of water for emergency settings and small communities. Trans R Soc Trop Med Hyg. 2006;100:863-6.

19. Rose A, Roy S, Abraham V, Holmgren G, George $\mathrm{K}$, Balraj V, et al. Solar disinfection of water for diarrhoeal prevention in southern India. Arch Dis Child. 2006;91:139-41.

20. Arnold BF, Colford JM Jr. Treating water with chlorine at point-of-use to improve water quality and reduce child diarrhoea in developing countries: a systematic review and meta-analysis. Am J Trop Med Hyg. 2007;76:354-64.

21. Mintz ED, Reiff FM, Tauxe RV. Safe water treatment and storage in the home. A practical new strategy to prevent waterborne disease. JAMA. 1995;273:948-53.

22. Clasen T, Roberts I, Rabie T, Schmidt W, Cairncross S. Interventions to improve water quality for preventing diarrhoea. Cochrane Database Syst Rev. 2006;3:CD004794.

23. Zwane AP, Kremer M. What works in fighting diarrheal diseases in developing countries? a critical review. Boston: Center for International Development at Harvard University. 2007. Available at: http://www.economics.harvard.edu/faculty/kremer/p apers/wbro.pdf. Accessed on $23^{\text {rd }}$ February 2014.

24. Howe AD, Forster S, Morton S, Marshall R, Osbrn $\mathrm{KS}$, Wright $\mathrm{P}$, et al. Cryptosporidium oocysts in a water supply associated with a cryptosporidiosis outbreak. Emerg Infect Dis. 2002;8:619-24.

25. Licence K, Oates KR, Synge BA, Reid TM. An outbreak of E. coli O157 infection with evidence of spread from animals to man through contamination of a private water supply. Epidemiol Infect. 2001;126:135-8.

26. Trevett AF, Carter R, Tyrrel S. Water quality deterioration: a study of household drinking water quality in rural Honduras. Int J Environ Health Res. 2004;14:273-83.

27. International Institute for Population Sciences (IIPS) and Macro International. National Family Health Survey (NFHS-3), 2005-06. Mumbai, India. IIPS;2007.

28. Bhattacharya M. Water handling and sanitation practices in rural community of madhya pradesh: a knowledge, attitude and practice study. Indian $\mathrm{J}$ Prev Soc Med. 2011;42(1).

29. Output 1 of WHO contract 1265: Guidance on communication with respect to safe drinking water and household hygiene. WHO cranfield.pdf.

30. Knowledge, attitude and practice: IRC international water and sanitation center. Available at: http://www.ircwash.org/ sites/default/files/822-9616013.pdf. Assessed on $24^{\text {th }}$ February, 2014.

31. Tamilnadu: availability and type of latrine facility, 2011. Available at: http://www.census.tn.nic.in/ HLO_Datasheet_Final/HLO_Datasheet_Latrine_Pa ge1.pdf. Assessed on $25^{\text {th }}$ February, 2014. 
32. Bora D, Dhariwal AC, Jain DC, Sachdeva V, Vohra JG, Prakash RM, et al. V. cholerae O1 outbreak in remote villages of Shimla district, Himachal Pradesh, 1994. J Commun Dis. 1997;29:121-5.

33. Sarkar R, Prabhakar AT, Manickam S, Selvapandian D, Raghava MV, Kang G, et al. Epidemiological investigation of an outbreak of acute diarrhoeal disease using geographic information systems. Trans R Soc Trop Med Hyg. 2007;101:587-93.

34. Curtis V, Danquah LO, Aunger RV. Planned, motivated and habitual hygiene behaviour: an eleven country review. Health Educ Res. 2009;4:655-73.

35. United Nations Children's Fund. Soap, toilets, and taps. A foundation for healthy children, February 2009. Available at www.unicef.org/wash/files/final. Accessed on $27^{\text {th }}$ February 2014.

36. Sah RB, Baral DD, Ghimire A, Pokharel PK. Knowledge \& practice of water \& sanitation application: Health Renaissance 2013;11(3):241245.

37. Lopez-Quintero C, Freeman P, Neumark Y. Hand washing among school children in Bogota, Colombia. Am J Public Health. 2009;99:94-101.

38. Banda K, Sarkar R, Gopal S. Water handling, sanitation and defecation practices in rural southern India: a knowledge, attitudes and practices study Trans R Soc Trop Med Hyg. 2007;101:1124-30.

39. Gorter AC, Sandiford P, Pauw J. Hygiene behavior in rural Nicaragua in relation to diarrhoea. Int $\mathrm{J}$ Epidemiol. 1998;27:1090-100.

Cite this article as: Pachori R. Drinking water and sanitation: household survey for knowledge and practice in rural area, Magudanchavadi, Salem district, India. Int J Community Med Public Health 2016;3:1820-8. 


\section{APPENDIX}

1. Premises: Space with physical boundary where the household lived.

2. Household: A group of persons who normally live together and take their meal from common kitchen unless the exigencies of work prevents any of them from doing so.

3. Income classification: Modified B.G. Prasad revised income categories for all India (IW) 2014 was used for assessment of economic status. Re-categorisation of modified B.G. Prasad revised income categories for all India (IW) 2014 in convenient form for feasibility of study.

\begin{tabular}{|c|c|c|c|}
\hline \multicolumn{2}{|c|}{$\begin{array}{l}\text { Modified B.G. Prasad revised income categories for all } \\
\text { India (IW) } 2014\end{array}$} & $\begin{array}{l}\text { Convenient } \mathbf{f} \\
\text { income categ }\end{array}$ & $\begin{array}{l}\text { B.G. Prasad revised } \\
\text { lia (IW) } 2014\end{array}$ \\
\hline Upper class & 5357 and above & \multirow{2}{*}{ Upper class } & \multirow[t]{2}{*}{2652 and above } \\
\hline Upper middle class & $2652-5356$ & & \\
\hline Middle class & $1570-2651$ & \multirow[t]{2}{*}{ Middle class } & \multirow[t]{2}{*}{$812-2651$} \\
\hline Lower middle class & $812-1569$ & & \\
\hline Lower class & 811 and below & Lower class & 811 and below \\
\hline
\end{tabular}

